\title{
Inclusive Education and the Causes of School Dropout: The Case of the Kadey Division of Batouri; East Region of Cameroon
}

\author{
${ }^{1}$ Maurice Wedjou Ndjouma*, ${ }^{2}$ Alain Villard Ndi Isoh, \\ ${ }^{1,2}$ ICT University
}

\begin{abstract}
The United Nations' Sustainable Development Agenda for inclusive education has pushed governments in several countries to sign international treaties and conventions to adopt policies and promote equal access to education by every child as a basic human right. Providing all people with education represents a fundamental part of the essential and ultimate aim of enhancing individual happiness and well-being. Nonetheless, for some reasons the objectives for inclusive education have been inhibited by variety of factors resulting to high rate of illiteracy and unprecedented school drop outs most especially in developing countries. It is on this premise that this study is aimed at exploring factors influencing school dropout in the Kadey Division of Batouri; East region of Cameroon. The study is supported by the philosophical underpins of subjectivism ontology and interpretivism epistemology and data was sourced using in-depth interview involving four (4) focus groups consisting of twenty (20) education stakeholders in the Kadey division of Batouri. The analysis was concluded using grounded theory approach and the principle of theoretical saturation was observed to justify the appropriateness of the sample size. The study revealed that school dropout in the Kadey division is influenced principally by economic factors consisting of employment opportunities and financial constraint. The availability of mining activities create opportunities for unskilled jobs for pupils and students whereas, extreme poverty prevents parents to cover school expenses. Other factors such as inadequate infrastructure social, cultural, political and pedagogy constrains were equally identified. This study recommends that academic stakeholders through the ParentTeachers Association should work closely with the parents to encourage their children of the necessities of quality and sustainable education. It is essential for parents to be aware of the importance of education and to take appropriate measures to keep sending their children to school and fulfil their goals. The government on their part should provide assistance such as infrastructure and teachers to support school administrators achieve academic objectives in the Kadey Division of Batouri East Cameroon.
\end{abstract}

Keywords: School dropouts, Kadey Division, East Cameroon

\section{Introduction}

The fundamental premise of inclusive education is anchored on the view that every child has the right to education (UNICEF, 2018). This statement has been reinforced by article N0 96/06 of January 15, 1996 by the government of Cameroon which makes basic education tuition free. The education sector was allotted over 675 billion FCFA of the 2019 budgetary session in Cameroon (Mfoungo, 2019). The question of inclusive education has been highlighted by the United Nations Sustainable Development Goal of 2030 which stressed on the need of education for all. The current vision of education is to promote inclusive education, equitable education as well as quality education; and to encourage permanent learning opportunities and openings for all. (UNESCO; UNICEF; World Bank; UNFPA; UNDP; UN Women; UNHCR, 2015). However, the impediment of inclusive education has been an issue of growing concern. In 2015, 144 schools were closed in Cameroon's Far North region, caused by Boko Haram insurgencies leaving 36,000 pupils with no access to education (Norwegian Refugee Council, 2018). Equally, the northwest and southwest regions of Cameroon are faced with exceptionally high rate of school dropout due to political instability caused by the anglophone crises (Kuwomu, 2019).

The case of school dropout in the East Region of Cameroon is far from being motivated by political uncertainty and terrorism compare to the other regions. The following statistics depict the state of school 
dropout in the Kadey division of the East region of Cameroon. According to statistics from the delegation of education in the Kadey division for the academic year of 2016-2017, a total of 10,871 students enrolled at the start of the school year for the three different subsections: Anglophone, Francophone and Technical subsections. A total of 8,801 effectively finished the school year while 2,070 students dropped out (Ministry of Education: Kadey Divisional Education, 2019). Furthermore, at the 2017-2018 academic years, 10,461 students enrolled but just 7,838 finished the academic year and 2623 dropped out. Similarly, for the school year 2018-2019 a total of 9,969 students registered and only 6,758 made it to the end and an estimated 33\% dropped out (Ministry of Education: Kadey Divisional Education, 2019). These statistics are shown below for the respective subsections of education.

Table 1: Enrolment for the School Year: 2016-2017

\section{Enrolment School Year : 2016-2017}

\begin{tabular}{|c|c|c|c|c|c|c|c|c|}
\hline \multicolumn{3}{|c|}{ Francophone Section } & \multicolumn{3}{|c|}{ Anglophone Section } & \multicolumn{2}{|c|}{ Technical Section } & \multirow[b]{2}{*}{ ES } \\
\hline CLASSES & $\mathrm{BS}$ & ES & CLASSES & $\mathrm{BS}$ & ES & CLASSES & $\mathrm{BS}$ & \\
\hline 6 & 1620 & 1482 & Form 1 & 195 & 135 & 1ere & 982 & 760 \\
\hline 5 & 1345 & 1213 & Form 2 & 89 & 22 & 2eme & 736 & 569 \\
\hline 4 & 1209 & 1077 & Form 3 & 126 & 57 & 3eme & 530 & 354 \\
\hline 3 & 1419 & 1287 & Form 4 & 95 & 19 & 4eme & 489 & 400 \\
\hline 2 & 583 & 446 & Form 5 & 86 & 20 & 2nd & 95 & 39 \\
\hline 1 & 723 & 591 & Lower sixth & 29 & 21 & 1 & 124 & 50 \\
\hline Tle & 324 & 192 & Upper sixth & 10 & 8 & Tle & 62 & 59 \\
\hline Total & 7223 & 6288 & Total & 630 & 282 & Total & 3018 & 2231 \\
\hline
\end{tabular}

Source: Ministry for Secondary Education, East Regional Education: Kadey Division Delegation,

\section{Batouri}

Table 2: Enrollment School Year : 2017-2018

\begin{tabular}{|l|l|l|l|l|l|l|l|l|}
\hline \multicolumn{7}{|l|}{ Enrollment School Year : 2017-2018 } \\
\hline \multicolumn{3}{|l|}{ Francophone Section } & \multicolumn{2}{l|}{ Anglophone Section } & \multicolumn{2}{l|}{ Technical Section } & \\
\hline CLASSES & BS & ES & CLASSES & BS & ES & CLASSES & BS & ES \\
\hline 6 & 1773 & 1288 & F1 & 126 & 57 & 1 ere & 985 & 708 \\
\hline 5 & 1245 & 950 & F2 & 80 & 10 & 2 eme & 532 & 471 \\
\hline 4 & 1118 & 890 & F3 & 72 & 28 & 3 eme & 431 & 332 \\
\hline 3 & 1277 & 1156 & F4 & 56 & 17 & 4 eme & 453 & 354 \\
\hline 2 & 695 & 557 & F5 & 57 & 31 & $2^{\text {nd }}$ & 116 & 25 \\
\hline 1 & 696 & 667 & L6 & 31 & 16 & 1 & 70 & 28 \\
\hline Tle & 365 & 239 & UP6 & 26 & 10 & Tle & 9 & 4 \\
\hline Total & 7169 & 5747 & Total & 696 & 169 & Total & 2596 & 1922 \\
\hline
\end{tabular}

Source: $\quad$ (Ministry of Education: Kadey Divisional Education, 2019) 
Table 3: Enrolment School Year: 2018-2019

\begin{tabular}{|l|l|l|l|l|l|l|l|l|}
\hline \multicolumn{2}{|l|}{ Enrolment School Year : 2018-2019 } & \multicolumn{2}{l|}{ Technical Section } & \\
\hline French Section & \multicolumn{2}{|l|}{ English Section } & CLASSES & BS & ES & CLASSES & BS & ES \\
\hline CLASSES & BS & ES & F & 186 & 69 & 1 ere & 979 & 771 \\
\hline 6 & 1416 & 1117 & F1 & 81 & 52 & 2 eme & 656 & 441 \\
\hline 5 & 1299 & 998 & F2 & 96 & 58 & 3 eme & 502 & 398 \\
\hline 4 & 1133 & 706 & F3 & 89 & 54 & 4 eme & 471 & 309 \\
\hline 3 & 1249 & 871 & F4 & 76 & 48 & $2^{\text {nd }}$ & 87 & 53 \\
\hline 2 & 512 & 217 & F5 & 24 & 12 & 1 & 107 & 61 \\
\hline 1 & 671 & 358 & L6 & 11 & 7 & Tle & 55 & 41 \\
\hline Tle & 269 & 117 & UP6 & 563 & 300 & Total & 2857 & 2074 \\
\hline Total & 6549 & 4384 & Total & & & & \\
\hline
\end{tabular}

\section{Source: (Ministry of Education: Kadey Divisional Education, 2019)}

Table 4: Enrolment School Year: 2016-2019

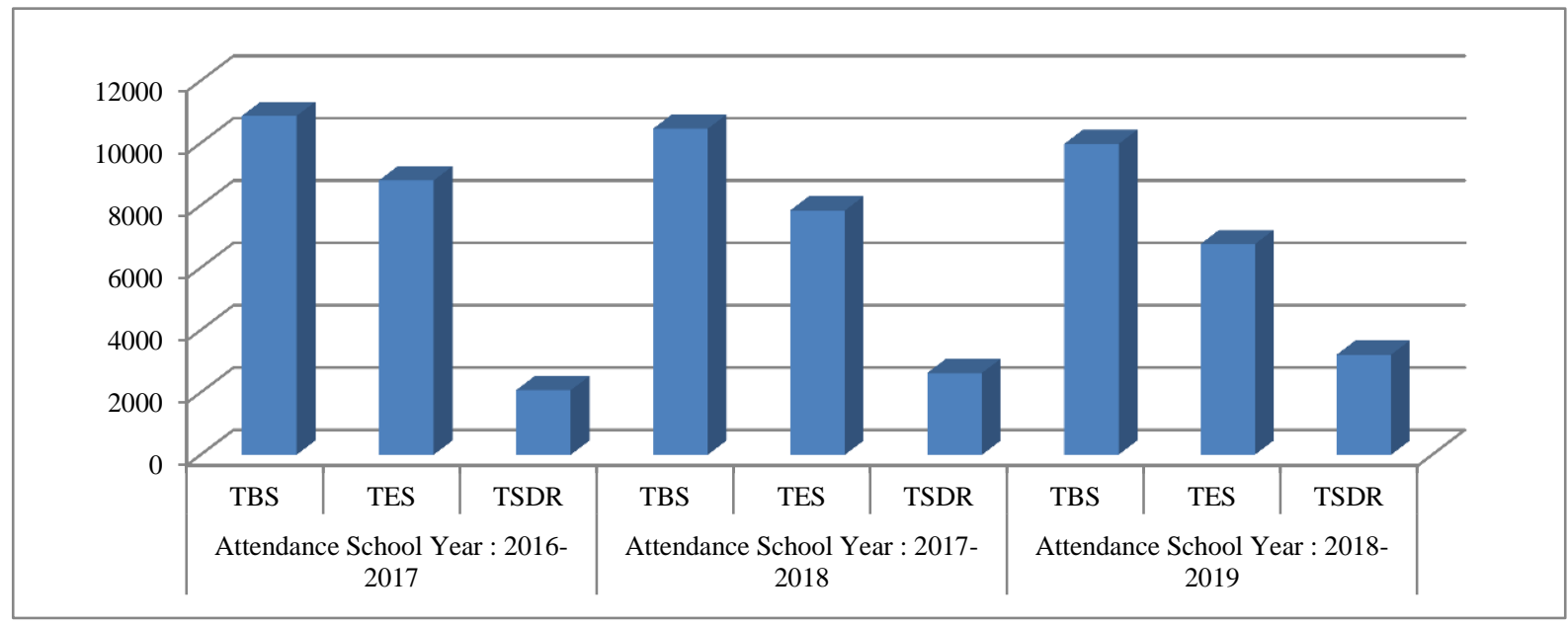

Source: (Ministry of Education: Kadey Divisional Education, 2019)

BS: Number of Students Enrolled at the Beginning of School Year

ES: Number of Students at the End of the School Year

TBS: Total Number of Students Attendance Beginning of School Year all Sections

TES: Total Number of Students Attendance End of School Year all Sections

TSDR: Total Number of Students Drop out at the End of School Year

The aforementioned situation is risky for the community as the region is strongly characterised by limited access to basic educational services. The rural area of Batouri is remarkable for its very low rate of literacy in Cameroon. Less than $50 \%$ of pupils have access to education and as such, the division has been classified as an Education Prioritized Zone (CORDAID, 2012). Based on the aforementioned statistical evidence, this study is aimed at exploring factors responsible for school dropout in the rural areas of Batouri (UIS 2016; Norwegian Refugee Council 2018). This study adds to existing literature on inclusive education in the case of the East Region of Cameroon.

\subsection{Literature Review}


This study addressed two key themes: school dropout and inclusive education. School dropout relates to situation of unprecedented termination of studies or the discontinuing of schooling (López, Opertti, \& Vargas Tamez, 2019) whereas, inclusive education is the opportunity for equal and fair education (mcmanis, 2017). The abovementioned concepts are buttressed by the Student Development Theories and Educational Leadership Theories. These theories provides platform to underscore school dropout as explored in this research.

\subsection{The Student Development Theory (SDT)}

The learning process is an academic journey (Abiddin \& Affero, 2012). It ranges from very young pupils to adults (Knowles, 1978). The Student Development Theory provides framework to know student develop process (Abiddin \& Affero, 2012). This theory enables school administrators and stakeholders to recognise and understand students' behaviours, attitudes and experiences. Such behaviour and altitudes shape the learning process of students. Promoting high expectations towards all students is essential to reducing the achievement gap that may exist between the privileged and the less privileged students. (The Wallace Foundation, 2013). The Student Development Theories are often based on psychological theories (Evans, Forney, Guido, Patton, \& Penn, 2010). In general, there are four key theories on aspects relating to students' development: Psycho-Social Theories, Cognitive-Structural Theories, Person Environment Interactive Theories and Humanistic Existential Theories (Abiddin \& Affero, 2012). The implication of student development theory is anchored on identifying new knowledge relevant to improve on the learning environments usually in schools (National Research Council, 2000). It has been argued that Student Development Theories are useful in developing strategies to promote student learning, understanding and managing change (Abiddin \& Affero, 2012). As mentioned by (Chickering \& Reisser, 1993), developing competence with specific attention on intellectual, physical, manual, and interpersonal qualities are major objectives of student development. Knowledge on student development would help school administrators to proactively identify and mitigate circumstances of school dropout phenomenon in the school environment.

\subsection{The Educational Leadership Theory}

Educational leadership theories relates to understanding and managing educational stakeholders and their respective interests. It can also be interpreted as a procedure of influence driving to the achievements and accomplishments of desired commitments or purposes. (Ali \& Abdalla, 2017). This involves managing school administrators, teachers, students, and parents with the intention to achieve educational objectives. Therefore; the majority of school decisions should be taken upon consultation with relevant stakeholders to make meaningful impact on the learning process. Consequently, educators must create interactive platforms with other stakeholders to improve the education process. To this effect, educators holding school leadership positions are well placed to guarantee effective collaboration (Day \& Sammons, 2016). By extension, the educational leadership theory emphasizes on strategies that educational administrators use within school systems to enhance school attendance, student performance, parents- teachers cooperation with the intention to minimize school dropout and guarantee quality and sustainable education (Day \& Sammons, 2016). Generally, there are three theories of Education leadership: transformational leadership, instructional leadership, and administrative leadership (Sheahan, 2019). All these theories provide essential knowledge to assist school administrators to mitigate school dropout with collaborative efforts from all stakeholders within the school community (Hoque \& Ahmad, 2014)

\subsection{Methodology}

This research is an exploratory case study design (Kothari, 2004; Ming, 2005; Creswell, 2003). The philosophical underpins were subjectivism ontology and interpretivism epistemology. The research is inductive and the axiology is value-bias. Data was analysed using grounded theory approach involving: open, axial, and selective coding processes (Glaser \& Strauss, 1967; Corbin, Juliet, \& Strauss, 1990). A sample size of Four (4) focus groups involving twenty (20) participants were purposive sampled from a population of educational stakeholders of the Kadey division of East region of Cameroon. Findings were checked for internal and external validity based on credibility, dependability, conformability, and transferability parameters (Polit \& Hungler, 1995).

\subsection{Data Analysis and Presentation of Results}


The first step of grounded theory analysis is the exploration of opinions and narratives of participants into codes regarding the causes of school dropouts as shown below.

Table 4: Open Coding and Theoretical Saturation

\begin{tabular}{|c|c|c|c|}
\hline FG & Categories & Abbre. & Narratives /codes/ opinions \\
\hline \multirow[t]{6}{*}{ 1: } & Cultural & CUL & $\begin{array}{l}{[\ldots] \text { Diverse culture involving the minority Baka people and Bantu }} \\
\text { majority. The minority are marginalized and excluded from school. }\end{array}$ \\
\hline & Social & SOC & $\begin{array}{l}{[\ldots] \text { In Families organised projects, children and women are forced to }} \\
\text { participate }\end{array}$ \\
\hline & Financial & FIN & $\begin{array}{l}{[\ldots] \text { Some parents are so poor and cannot afford to send their children to }} \\
\text { school. }\end{array}$ \\
\hline & Political & POL & $\begin{array}{l}{[\ldots] \text { Politicians are not able to boost education through school related }} \\
\text { projects }\end{array}$ \\
\hline & Infrastructure & INF & [...]The lack of adequate school infrastructure and school building. \\
\hline & Pedagogy & PED & {$[\ldots]$ Teacher volunteers are not trained. The lack of human teachers. } \\
\hline \multirow[t]{4}{*}{ 2: } & Employment & EMP & $\begin{array}{l}{[\ldots] \text { Students dropout to work at mining sites (gold), parents discourage }} \\
\text { children to attain school but work in mines and farms to make quick } \\
\text { money }\end{array}$ \\
\hline & Cultural & CUL & $\begin{array}{l}{[\ldots] \text { The marginalized bantu are forced to leave school and flee in the }} \\
\text { forest }\end{array}$ \\
\hline & Financial & FIN & {$[\ldots]$ Extreme poverty of people living in the rural areas of Batouri. } \\
\hline & Infrastructure & INF & [...] ]lack of infrastructure and school buildings \\
\hline \multirow[t]{4}{*}{3} & Financial & FIN & $\begin{array}{l}{[\ldots] \text { Extreme poverty of the majority of parents in the rural area of }} \\
\text { Batouri. }\end{array}$ \\
\hline & Employment & EMP & [...]Children prefer to work in the mines as opposed going to school \\
\hline & Political & POL & [...]Politicians do not support education in the Kadey division \\
\hline & Infrastructure & INF & {$[\ldots]$ There are no schools in some villages } \\
\hline 4: & Social & SOC & $\begin{array}{l}{[\ldots] \text { The community or family members are not supportive to the }} \\
\text { children after facing dramatic situations such as the death of their } \\
\text { parents. }\end{array}$ \\
\hline
\end{tabular}

\section{Source: Field notes (2019)}

Based on the table above, seven categories were identified as causes of school dropout in the Kadey Division of Batouri, East region of Cameroon. These factors include: social, cultural, political, financialpoverty, employment, pedagogy and infrastructural factors. These categories are further regrouped as shown on the axial coding process below.

\section{Table 2: Axial Coding}

\begin{tabular}{|l|l|l|}
\hline Question & Cat & Narratives / Description / codes \\
\hline $\begin{array}{l}\text { Factors responsible for early school } \\
\text { dropouts in the rural areas of the } \\
\text { Kadey Division, East Region of } \\
\text { Cameroon? }\end{array}$ & $\begin{array}{l}{[\ldots] \text { Diverse culture where the minority Baka }} \\
\text { people and bantu majority. } \\
{[\ldots] \text { The marginalized bantu are forced to leave }} \\
\text { school and flee in the forest }\end{array}$ \\
\hline
\end{tabular}




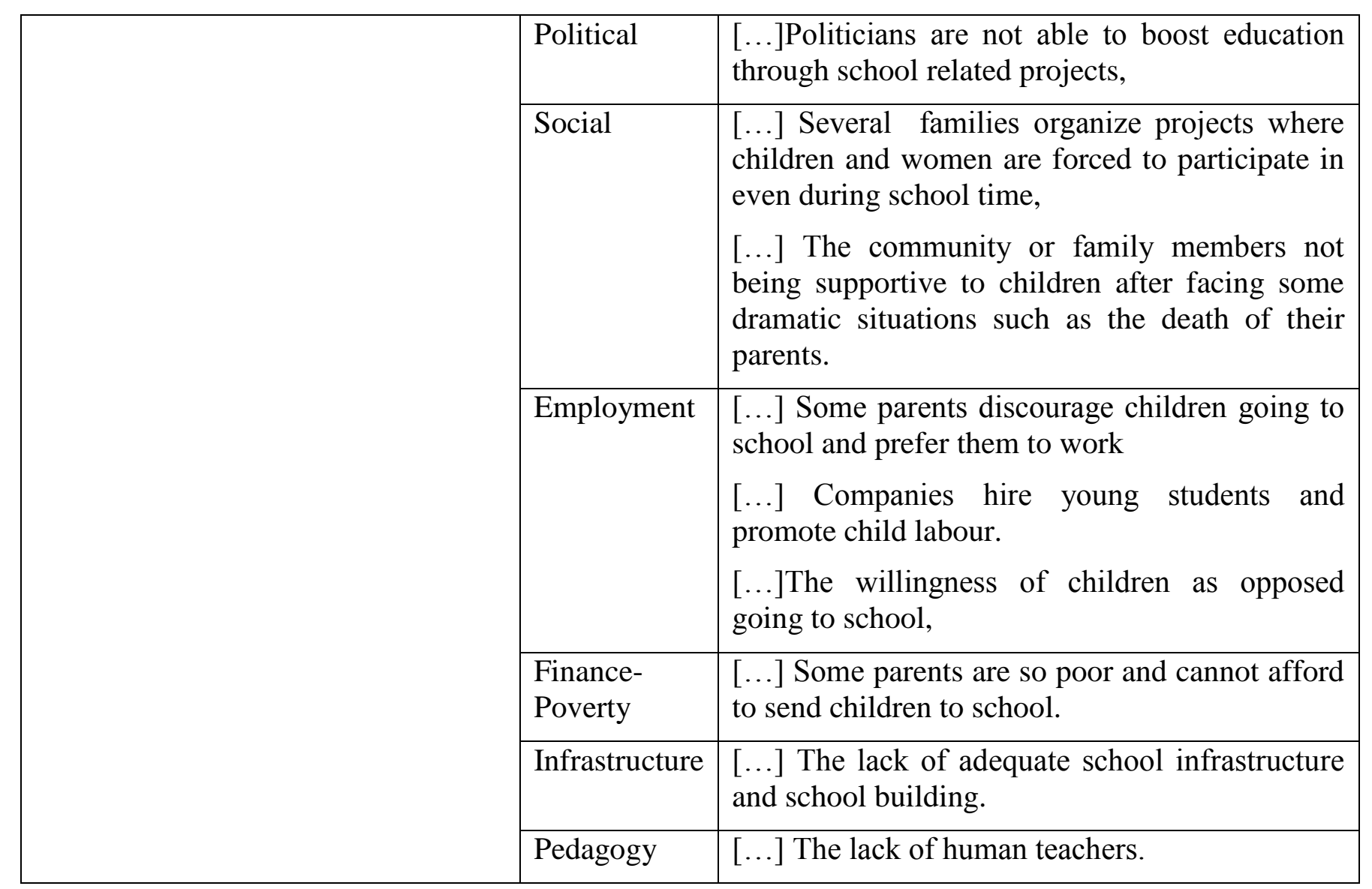

\section{Source: Field Data (2019)}

\section{Memo:}

I. Cultural influence: Diverse culture leading to the minority being marginalised and excluded from school.

II. Politicians do not effectively involve in the growth of education in the Kadey division.

III. Social influence: Families organised projects where children and women are forced to participate even during school time. Family members and community do not support children after facing dramatic situations such as the death of their parents.

IV. Economic influence: Students dropout to work in mining exploitation- gold, Some parents discourage their children from going to school and prefer them to get involved in activities such as mining, tobacco, farming, petite trading to make quick and easy money. Companies hire young students and promote child labour. Children are willing to work in the mining and tobacco companies as opposed to going to school,

V. Financial influence: Some parents are so poor that they cannot afford to send children to school.

VI. Infrastructure issues: There are no schools in some villages, and with no public transportation. Some students are required to attained schools in other villages sometimes trekking for about 10-15 kilo-meters per day covering between 50-75 kilometres per week. This is very challenging and discouraging for those children causing them to get involved in other activities.

VII. Pedagogy constraint: Teacher volunteers at the secondary level are not trained. Most schools lack human resources; mostly teachers. At any step of education, teachers give the necessary tools and setting for their children or students to grow toward becoming responsible adults.

Table 4: Selective Coding

\begin{tabular}{|l|l|l|l|}
\hline Question & Categories & Narratives/Description & RK \\
\hline $\begin{array}{l}\text { Factors } \\
\text { responsible } \\
\text { for early }\end{array}$ & Cultural & $\begin{array}{l}{[\ldots] \text { The marginalized of the minority bantu who are forced to }} \\
\text { leave school }\end{array}$ & 2 \\
\cline { 2 - 4 } & Political & {$[\ldots]$ Politicians do not effectively implicate themselves in } & 2 \\
\hline
\end{tabular}




\begin{tabular}{|c|c|c|c|}
\hline \multirow{6}{*}{$\begin{array}{l}\text { school } \\
\text { dropouts in } \\
\text { the rural } \\
\text { areas of the } \\
\text { Kadey } \\
\text { Division, } \\
\text { East Region } \\
\text { of } \\
\text { Cameroon? }\end{array}$} & & education & \\
\hline & Social & $\begin{array}{l}{[\ldots] \text { Several families organize projects where children and }} \\
\text { women are forced to participate in even during school time, The } \\
\text { community or family members not being supportive to the } \\
\text { children after facing some dramatic situations such as the death } \\
\text { of their parents. }\end{array}$ & 2 \\
\hline & $\begin{array}{l}\text { Employme } \\
\text { nt }\end{array}$ & $\begin{array}{l}\text { [...] Students dropout to get involved in mining, some parents } \\
\text { discourage children from going to school for fast cash activities, } \\
\text { companies hire young students and promote child labour, } \\
\text { children willing to work in the mining and tobacco companies as } \\
\text { opposed of going to school, }\end{array}$ & 3 \\
\hline & Finance & $\begin{array}{l}\text { [...] Some parents are so poor and cannot afford to send } \\
\text { children to school }\end{array}$ & 3 \\
\hline & $\begin{array}{l}\text { Infrastructu } \\
\text { re }\end{array}$ & $\begin{array}{l}\text { [...]The lack of adequate school infrastructure and school } \\
\text { building. }\end{array}$ & 3 \\
\hline & Pedagogy & [...]The lack of human resources; mostly teachers & 1 \\
\hline
\end{tabular}

\section{Source: Field Data (2019)}

Figure 2: Modelling a framework for School dropout

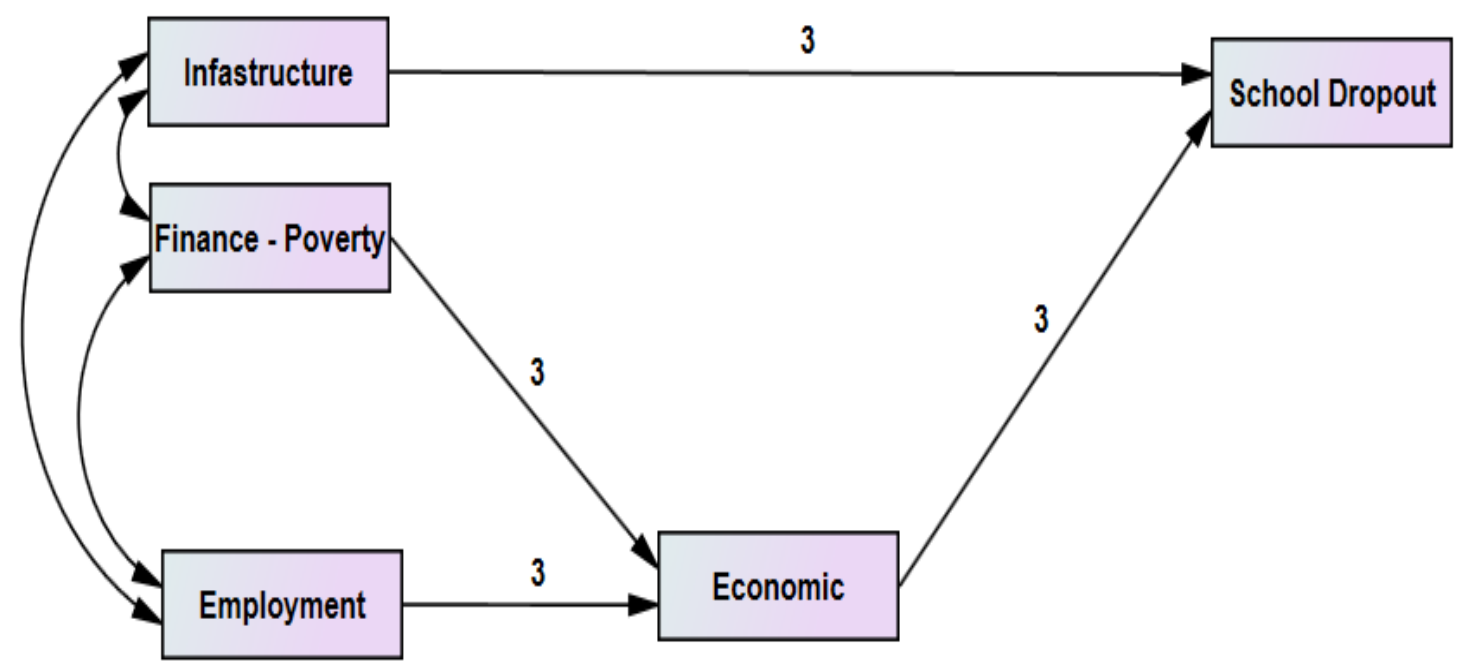

\section{Source: Field Data (2019)}

The selective coding table expresses how much each factor is influencing the phenomenon of school dropout. The above model illustrates that school dropout is largely explain by employment, poverty and the lack of infrastructure in the Kadey division of Batouri East region of Cameroon.

\subsection{Discussions and Conclusion}

Throughout the analysis; several factors causing school dropout within the locality of the rural areas of Batouri have been identified. These factors include: social, political, cultural, economic, financial, infrastructure, pedagogy and employment. The socio-economic causes represent a major factor of school dropout in many countries in Africa. According to (UNESCO, 2001), majority of people are not able to send their children to school and support them because they cannot afford tuition. This supports (World Bank, 1995) and (UNICEF, 1995) reports which emphasised that because of high level of poverty, majority of Kenyans have trouble accessing education (Michubu, 2012). This situation remains the same nowadays in Kenya as well as in Cameroon. Children are therefore forced to drop out and seek employment in order to avoid poverty. Child labour is mainly focused in two continents including Asia and Africa, and this represents about 90 percent of the entire child employment of the world. (Siddiqi \& Patrinos, 1995). 
Exploring the causes of school dropout in the Kadey division of Batouri is a step forward to promote the Education For All (EFA) with the purpose to meet the basics learning needs of the majority of children, adolescent and adults. (UNESCO, 2015)

\section{Referencing}

[1.] Abiddin, N. Z., \& Affero, I. (2012). Exploring Student Development Theory in Enhancing Learning through Supervision. International Journal of Academic Research in Progressive Education and Development, 1(1), 213-217.

[2.] Ali, I., \& Abdalla, M. (2017). Educational Management, Educational Administration and Educational. SAS Journal of Medicine (SASJM).

[3.] Chickering, A. W., \& Reisser, L. (1993). Education and identity. San Francisco: Jossey-Bass.

[4.] CORDAID. (2012). Projet PBF-Education. Batouri: Diocese de Batouri. Codas-Caritas.

[5.] Day, C., \& Sammons, P. (2016). Successful school leadership.

[6.] Glaser, B. G., \& Strauss , A. L. (1967). The Discovery of grounded Theory: Strategies for Qualitative Research. Chicago: Aldine Publishing Company.

[7.] Ming, K. E. (2005.). Research Questions and Research Objectives. The Family Physician.

[8.] Corbin, Juliet, \& Strauss, A. (1990). Grounded Theory Research Approach: Procedure Canons and Evaluative Criteria (Vol. 13).

[9.] Creswell, J. (2003). Research design: qualitative, quantitative, and mixed methods approaches (2nd Edition), . Thousand Oaks, CA: Sage Publications.

[10.] Kothari, C. R. (2004.). Research Methodology Methods \& Techniques. New Age International (P) Ltd., Publishers.

[11.] Evans, N. J., Forney, S. D., Guido, M. F., Patton, D., \& Penn, K. A. (2010). Student development in college: Theory, research, and practice (2nd ed.). San Francisco: Jossey-Bass Publishers.

[12.] Hoque, K., \& Ahmad, K. (2014, Munich). Human Resource Managers in Education. Their Roles in School Effectiveness.

[13.] HSBC. (2018, August 15). The Value of Education : The price of success. The Cost of University Education.

[14.] Joshi, A., Mitra, A., Suya, D., Yadav, P., Bhardwaj, S., \& Kalra, S. (2013, July 8). Dropouts in Upper Primary and Secondary School.

[15.] Knowles, M. S. (1978). The Adult Learner: A Neglected Species. Houston. Gulf Publishing Co.

[16.] Kuwomu, F. (2019). Crisis worsens in Cameroon. Africa Renewal.

[17.] López, N., Opertti, R., \& Vargas Tamez, C. (2019). Youth and changing realities: rethinking secondary education in Latin America. Dropping out.

[18.] Mcmanis, L. D. (2017). What is inclusive education? Inclusive Education: What It Means, Proven Strategies, and a Case Study.

[19.] Mfoungo. (2019). Education: Budget 2019. Yaounde: Agence Cameroun Press.

[20.] Michubu, T. (2012, August 09). A Study Of The Causes Of Dropout In Public Primaryschools In Ndoleli Division, Igembe North District,Kenya. Nairobi, Africa.

[21.] Ministry of Education: Kadey Divisional Education. (2019). School Dropout in the Kadey Division. Batouri: Kadey Divisional Education.

[22.] National Research Council. (2000). How People Learn: Brain,Mind,Experience and School: Expanded Edition. Washington: The National Academic Press. 
[23.] Norwegian Refugee Council. (2018). Thousands of children out of school. Norway: Norwegian Refugee Council.

[24.] Polit, D. F., \& Hungler, B. P. (1995). Nursing Research: Principles and Methods. Philadelphia : JB Lippincott.

[25.] Sheahan, K. (2019). Types of Educational Leadership Theories.

[26.] Siddiqi, F., \& Patrinos, H. (1995). Child Labor: Issues, Causes And Interventions. Human Capital development and Operations Policy (HCO).

[27.] The Wallace Foundation. (2013, january). The School Principal As Leader:Guiding Schools To Better Teaching And Learning.

[28.] UIS 2016; Norwegian Refugee Council 2018. (n.d.). Thousands of Children Out of School; Leaving No One Behind.

[29.] UNESCO. (2001). Children Out of Schools: Measuring Exclusion From Primary Education. UNESCO.

[30.] UNESCO. (2015). Education For All. UNESCO.

[31.] UNESCO; UNICEF; World Bank; UNFPA; UNDP; UN Women; UNHCR. (2015). Towards inclusive and equitable qualityeducation and lifelong learning for all. Incheon: United Nation, Education 2030.

[32.] UNICEF. (2018). UNICEF's work in education. UNICEF.

[33.] United Nations. (2007). The United Nations Development Agenda:Development for All. New York: United Nations. 